Agro Ekonomi Vol. 27/No. 1, Juni 2016

\title{
STRATEGI PENGUATAN KELEMBAGAAN USAHA MINUMAN OLAHAN BERBAHAN BAKU SIRSAK DI KABUPATEN KEDIRI
}

\author{
Development Strategy of Soursop-Based Baverage Business in Kediri Regency
}

\author{
Novi Haryati, Arif Wahyu Setiawan dan Excel Virgi Swastika \\ Jurusan Sosial Ekonomi Pertanian Fakultas Pertanian Universitas Brawijaya \\ Jl. Veteran Kota Malang (65145) \\ noviharyati@ub.ac.id
}

Diterima tanggal : 13 Maret 2016 ; Disetujui tanggal : 18 April 2017

\begin{abstract}
Processing is one solution in handling perishable and durable agricultural products. This study aims to determine: (1) production-based region of soursop commodities in Kediri, (2) analysis of strengths, weaknesses, opportunities and threats in soursop-based small entreprise, and (3) strategy of institutional strengthening implemented within the business. Primary data was taken through interview and secondary data was derived from the Central Statistics Agency of Kediri from 2010 to 2015. Research location was determined by judgment sampling which is located in the small business of Wonojoyo Trisulo in Plosoklaten. Research shows that Beside Plosoklaten, $L Q$ analysis described other 12 production-based area of soursop in Kediri, such as Gurah, Kandat, Tarokan, Wates, Kepung, Ngancar, Mojo, Ngasem, Pagu, Gampengrejo, Semen, and Ngadiluwih. Those area will contribute as opponent for Plosoklaten to produce good quality product of soursop. SWOT analysis shows that the business's position is in quadrant IV (negative, negative) that indicates the condition of weak, because it has some weaknesses and threats from the outside environment more than the strength and opportunity. Damage Control considers as an appropriate strategy that can be done by conducting more market-oriented management. Human resources and technology are also needed to be improved in the future.
\end{abstract}

Keywords: $L Q$, region base, sirsak, SWOT

\section{INTISARI}

Pengolahan merupakan salah satu solusi dalam menangani produk pertanian yang mudah rusak dan tahan lama. Penelitian ini bertujuan untuk mengetahui: (1) daerah produksi komoditas sirsak di Kediri, (2) analisis kekuatan, kelemahan, peluang dan ancaman pada usaha kecil berbasis sirsak, dan (3) strategi penguatan kelembagaan yang dilaksanakan dalam usaha. Data primer diambil melalui wawancara dan data sekunder berasal dari Badan Pusat Statistik Kediri dari tahun 2010 sampai 2015. Lokasi penelitian ditentukan oleh sampling penilaian yang berada pada usaha kecil Wonojoyo Trisulo di Plosoklaten. Penelitian menunjukkan bahwa selain Plosoklaten, analisis LQ menggambarkan 12 daerah produksi sirsak lainnya di Kediri, seperti Gurah, Kandat, Tarokan, Wates, Kepung, Ngancar, Mojo, Ngasem, Pagu, Gampengrejo, Semen, dan Ngadiluwih. Daerah tersebut akan berperan sebagai sentra lain seain Plosoklaten untuk menghasilkan produk sirsak berkualitas. Analisis SWOT menunjukkan bahwa posisi bisnis berada pada kuadran IV (negatif, negatif) yang 
mengindikasikan kondisi lemah, karena memiliki beberapa kelemahan dan ancaman dari lingkungan luar lebih dari pada kekuatan dan kesempatan. Pengendalian kerusakan dianggap sebagai strategi tepat yang bisa dilakukan dengan melakukan manajemen yang berorientasi pasar. Sumber daya manusia dan teknologi juga perlu ditingkatkan di masa depan.

Kata Kunci : LQ, basis wilayah, sirsak, SWOT

\section{PENDAHULUAN}

Indonesia merupakan negara agraris yang dapat mencukupi kebutuhan pangan masyarakatnya dari sektor pertanian yang juga merupakan salah satu sumber pendapatan bagi sebagaian besar masyarakat khususnya di pedesaan. Bidang pertanian juga berkontribusi sebagai pemasok pangan pasar domestik guna untuk mengurangi ketergantungan terhadap impor pangan. Akan tetapi, peran sektor pertanian yang begitu penting bagi kontribusi perekonomian di Indonesia masih belum bisa dijadikan andalan karena masih banyak kelemahan, diantaranya adalah kurangnya pemenuhan produk olahan pertanian tanaman hortikultura.

Jika ditinjau dari keunggulan komparatif dan kompetitif yang dimilikinya, Hortikultura merupakan komoditas yang akan memiliki masa depan yang sangat cerah dalam rangka pemulihan perekonomian Indonesia waktu mendatang. Oleh karena itu, perlu dilakukan pengembangan produk hortikultura lebih lanjut.

Buah-buahan adalah salah satu jenis komoditi hortikultura yang tersedia dengan jumlah yang besar dan beragam. Keunggulan cita rasa yang dimiliki buah- buahan Indonesia tidak kalah dengan buah-buah dari negara lainnya. Peran sektor tanaman hortikultura tersebut begitu penting bagi kontribusi perekonomian di Indonesia. Akan tetapi sektor tersebut masih belum bisa dijadikan andalan utama karena banyaknya kelemahan, misalnya adalah mudah rusak dan masa simpannya yang singkat, sementara ketika sedang musim, produksinya dapat meningkat tajam. Hal tersebut menyebabkan komoditi hortikultura mudah busuk dan terbuang. Pengolahan buah-buahan menjadi produk yang memiliki masa simpan lebih lama dapat dijadikan solusi untuk mengatasi permasalahan tersebut. Dengan demikian, maka pengembangan pengolahan komoditi buah-buahan menjadi cukup prospektif untuk dilakukan. Keuntungan lainnya adalah meningkatnya nilai tambah pada produk olahan tersebut jika dibandingkan dengan menjual dalam kondisi buah yang tidak diolah (Hermawan dan Laksono, 2013).

Produk buah-buahan memiliki masa simpan yang singkat, sementara ketika sedang musimnya produksinya dapat meningkat tajam, di beberapa daerah bahkan terjadi over supply atau kelebihan persediaan dan hal tersebut menyebabkan 
buah-buahan mudah busuk dan terbuang percuma. Pengolahan buah-buahan menjadi produk yang memiliki masa simpan lebih lama bisa dijadikan solusi untuk mengatasi permasalahan tersebut. Adapun keuntungan lainnya dari pengolahan buah-buahan adalah meningkatnya nilai tambah pada produk olahan tersebut dibanding menjual dalam kondisi buah yang tidak diolah.

Salah satu komoditi buah yang cukup potensial untuk dikembangkan di Indonesia adalah buah sirsak. Menurut Hermawan dan Laksono (2013), buah sirsak memiliki tekstur lunak dengan rasa asam dan manis. Produk olahan buah ini belum banyak dikenal, sehingga sirsak biasanya dikonsumsi dalam bentuk segar atau jus. Kulit buah sirsak berwarna hijau dan daging buahnya berwarna putih dengan aroma yang khas. Sirsak memiliki manfaat untuk kesehatan tubuh karena sirsak mengandung vitamin $\mathrm{C}$ yang tinggi dan zat antioksidan yang baik untuk tubuh utamanya bagi sistem pencernaan. Selain mengandung karbohidrat, sirsak juga adalah sumber vitamin B1 dan juga fruktosa. Serat sirsak berkisar antara 3,3 gram per 100 gram.

Salah satu daerah penghasil sirsak di Jawa Timur adalah Kabupaten Kediri. Total produksi sirsak pada tahun 2014 aadalah sebesar 26.546 Kwintal. Kecamatan Plosoklaten merupakan salah satu kecamatan yang mengalami perkembangan cukup pesat setiap tahunnya dalam hal produksi sirsak (BPS Kabupaten
Kediri, 2015). Namun demikian, produksi tinggi tersebut tidak diimbangi dengan adanya pengolahan yang memadai. Hal tersebut dapat dilihat dari minimnya sarana pengolahan. Desa Wonojoyo Trisulo merupakan satu-satunya desa yang kelompok taninya memproduksi olahan sari sirsak dengan merek dagang AXI. Unit pengolahan dalam bentuk mesin masih sangat terbatas, dan hal ini diperburuk dengan pengelolaan yang belum terintegrasi dengan baik.

Berdasarkan permasalahan tersebut penelitian ini dilakukan untuk menjawab pertanyaan berikut:

1. Bagaimanakah produksi sirsat di Kecamatan Plosoklaten Kabupaten Kediri jika ditinjau dari kecamatankecamatan penghasil sirsak lainnya?

2. Bagaimanakah kondisi UMKM pengolahan berbahan baku sirsak milik Kelompok Tani Wonojoyo Trisulo Plosoklaten jika ditinjau dari kelebihan, kelemahan, tantangan dan peluang yang dihadapi?

3. Bagaimanakah strategi yang tepat untuk mengembangkan UMKM tersebut sebagai salah satu unit pengolahan andalan komoditas sirsak di Kecamatan Plosoklaten?

\section{Tinjauan Pustaka}

Penentuan komoditas unggulan merupakan langkah awal menuju pembangunan pertanian yang berpihak pada 
konsep efisiensi untuk meraih keunggulan komparatifdan kompetitifdalam menghadapi globalisasi. Salah satu pendekatan yang dapat digunakan untuk menginisiasi komoditas unggulan adalah metode Location Quotient (LQ) (Hendayana, 2003). Jenis data kuantitatif yang digunakan berupa jumlah produksi dan produksi tanaman pangan sebagai input analisis LQ (Rahayu, 2014).

Analisis SWOT dapat digunakan untuk strategi pengembangan yang ditinjau dari faktor eksternal peluang (oppurtunities) dan ancaman (threats) dengan faktor internal kekuatan (strenghts) dan kelemahan (weakness) (Rangkuti, 2006), sedangkan strategi yang dapat dilaksanakan pemerintah untuk pengembangan hortikultura adalah: Meningkatkan produktivitas lahan pertanian (perubahan teknologi dan inovasi, kebijakan ekonomi dan perbaikan sistem kelembagaan) dan investasi dalam sumberdaya manusia (Hermawan dan Laksono, 2013).

\section{METODE PENELITIAN}

Metode penelitian yang digunakan dalam penelitian ini adalah metode deskriptif analitik yang mempunyai ciriciri memusatkan diri pada pemecahan masalah yang aktual. Data yang disusun kemudian dapat dijelaskan (Mubyarto dan Soeratno, 1981 dalam Prihtanto, 2015). Penentuan lokasi penelitian dilakukan secara purposive atau sengaja, yaitu di UMKM Wonojoyo Trisulo, yang melakukan proses pengolahan sirsak menjadi produk minuman sari buah sirsak di Kecamatan Plosoklaten Kabupaten Kediri. Data yang digunakan adalah data primer yang berasal dari wawancara responden, yaitu pengurus UMKM Wonojoyo Trisulo dan juga anggota kelompok tani yang terlibat dalam produksi minuman sari buah tersebut. Data sekunder berupa data produksi sirsak didapatkan dari Badan Pusat Statistik Kabupaten Kediri dari tahun 2010 hingga 2015.

\section{Metode Analisis}

\section{Analisis LQ}

Analisis Location Quotient (LQ) menunjukkan daerah basis komoditas dalam suatu daerah tertentu. Hasil dari analisis LQ adalah pemetaan produksi sirsak, yang menunjukkan adanya pesaing dalam hal produksi dan pengolahan kelembagaan pada UMKM Wonojoyo Trisulo. Formulasi LQ menurut Wibowo dan Januar (1998) adalah:

$$
L Q_{i}=\frac{v_{i} / v_{t}}{V_{i} / V_{t}}
$$

Keterangan:

LQi = Location Quotient komoditas sirsak di suatu wilayah

vi $=$ Produksi sirsak di kecamatan-i

$\mathrm{vt}=$ Produksi sirsak Kabupaten Kediri

$\mathrm{Vi}=$ Total produksi sirsak di kecamatan-i

$\mathrm{Vt}=$ Total produksi sirsak di Kabupaten Kediri 
Kriteria pengambilan keputusan:

LQ >1; Wilayah-i merupakan basis produksi sirsak di Kabupaten Kediri.

LQ $<1$; Wilayah-i merupakan non basis produksi sirsak di Kabupaten Kediri

$L Q_{i=1}$; Wilayah-i merupakan wilayah basis produksi komoditas sirsak di Kabupaten Kediri, akan tetapi hanya cukup untuk kebutuhan wilayah sendiri.

Asumsi yang digunakan adalah :

1. Pola permintaan penduduk Kabupaten Kediri bersifat homogen artinya setiap penduduk di wilayah penelitian dianggap mempunyai pola permintaan yang sama dengan pola permintaan nasional.

2. Produksi komoditas sirsak di Kabupaten Kediri pertama-tama digunakan untuk memenuhi kebutuhan wilayah itu sendiri dan selebihnya digunakan untuk memenuhi kebutuhan luar wilayah.

\section{Perumusan Kondisi UMKM Wonojoyo Trisulo dengan Analisis SWOT}

Pendekatan kualitatif pada matriks SWOT menurut Rangkuti (2006), menampilkan delapan kotak yaitu, dua paling atas adalah kotak faktor eksternal (peluang dan tantangan), sedangkan dua kotak sebelah kiri adalah faktor internal (kekuatan dan kelamahan). Identifikasi faktor eksternal dan internal diperlukan untuk memahami kondisi secara menyeluruh pada UMKM Wonojoyo Trisulo.

\begin{tabular}{|c|c|c|}
\hline Internal & $\begin{array}{l}\text { Strengths (S) } \\
1 . \\
2 . \\
3 .\end{array}$ & $\begin{array}{l}\text { Weaknesses }(W) \\
1 . \\
2 . \\
3 .\end{array}$ \\
\hline $\begin{array}{l}\text { Threat }(\mathrm{T}) \\
1 . \\
2 . \\
3 .\end{array}$ & $\begin{array}{l}\text { Strategi ST } \\
\text { Cunakan S untuk } \\
\text { menghindari T }\end{array}$ & $\begin{array}{l}\text { Strategi WT } \\
\text { Minimalkan W dar } \\
\text { hindari T }\end{array}$ \\
\hline $\begin{array}{l}\text { Opportunity }(0) \\
1 . \\
2 . \\
3 .\end{array}$ & $\begin{array}{l}\text { Strategi SO } \\
\text { Gunakan S untuk } \\
\text { memanfaatkan } 0\end{array}$ & $\begin{array}{l}\text { Strategi WO } \\
\text { Atasi W dengan } \\
\text { memanfaatkan } 0\end{array}$ \\
\hline
\end{tabular}

Gambar 1. Faktor Internal dan Eksternal UMKM (Rangkuti, 2006)

\section{Perumusan Strategi dengan Analisis SWOT}

Empat kotak pada Analisis SWOT menggambarkan kotak yang berisi isu-isu strategis yang timbul, sebagai hasil titik pertemuan antara faktor-faktor internal dan eksternal produsen produk olahan sirsak.

Menurut Rangkuti (2006), Kombinasi antara faktor internal dan eksternal dalam Analisis SWOT akan sangat mempengaruhi kinerja UMKM Wonojoyo Trisulo. Langkah selanjutnya adalah mengaplikasikan kombinasi faktor eksternal berupa peluang dan ancaman dengan faktor internal berupa kekuatan dan kelemahan perusahaan atau organisasi untuk menghasilkan strategi pengembangan. Penentuan alternatif strategi terbaik dalam pengembangan UMKM sebaiknya dirumuskan setelah UMKM melakukan analisa pada kuadran manakah 
kondisi dan posisi UMKM saat ini. Hal ini dimaksudkan, agar pengambilan alternatif sesuai dengan kondisi internal dan eksternal yang dimiliki perusahaan dalam hal ini usaha mikro, kecil dan menengah pada saat ini.

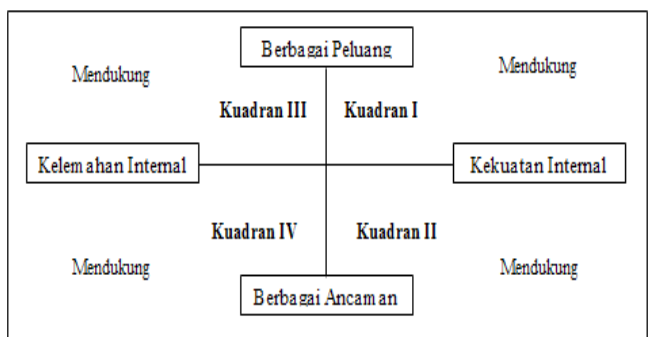

Gambar 2. Posisi Perusahaan dalam Empat Kuadran (Rangkuti, 2006)

a. Pada kuadran I, sebuah perusahaan disarankan menggunakan strategi agresif. Situasi perusahaan kuadran I sangat menguntungkan, dikarenakan letak perusahaan yang berada pada kondisi memiliki peluang dan kekuatan sehingga diharuskan untuk dapat memanfaatkan peluang yang ada.

b. Pada kuadran II, strategi perusahaan merupakan strategi diversifikasi. Perusahaan menghadapi situasi harus menghadapi berbagai ancaman dengan menggunakan kekuatan dari segi internal, sehingga memerlukan strategi yang mampu memanfaatkan peluang jangka panjang.

c. Pada kuadran III, strategi yang sesuai untuk diterapkan ialah turn around. Pada kondisi ini perusahaan memiliki peluang pasar yang besar akan tetapi disertai dengan munculnya kendala/ kelemahan internal yang cukup besar pula. Perusahaan perlu merumuskan strategi yang memungkinkan pengurangan kelemahan-kelemahan internalnya untuk dapat memanfaatkan peluang yang lebih baik.

d. Pada kuadran IV, diperlukan strategi defensif. Perusahaan mengalami kondisi yang sulit dimana harus menghadapi berbagai ancaman serta kelemahan internal perusahaan. Hal paling penting untuk dilakukan adalah perusahaan harus mampu mempertahankan diri.

\section{HASIL DAN PEMBAHASAN}

\section{Analisis Location Quotient}

Penentuan komoditas unggulan nasional dan daerah merupakan langkah awal meraih keunggulan kompetitifdan komparatif. Metode LQ telah mengidentifikasikan daerah basis yang merupakan sentra komoditas sirsak di Kabupaten Kediri.

Tabel 1. Hasil Analisis LQ

\begin{tabular}{lll}
\hline No & Kecamatan & LQ \\
\hline 1 & Plosoklaten & 12,88 \\
2 & Gurah & 7,01 \\
3 & Kandat & 4,63 \\
4 & Tarokan & 3,39 \\
5 & Wates & 3,31 \\
6 & Kepung & 3,12 \\
7 & Ngancar & 2,70 \\
8 & Mojo & 2,36 \\
9 & Ngasem & 1,87 \\
10 & Pagu & 1,68 \\
11 & Gampengrejo & 1,59 \\
12 & Semen & 1,54 \\
13 & Ngadiluwih & 1,06 \\
\hline
\end{tabular}

Sumber: Analisis Data Primer Tahun 2015 
Tabel 1 menunjukkan adanya 13 wilayah kecamatan basis yang merupakan sentra komoditas sirsak di Kabupaten Kediri, sedangkan nilai LQ keseluruhan kecamatan dalam Kabupaten Kediri dapat dilihat pada Lampiran 1. LQ menunjukkan lebih dari 1 pada Kecamatan Plosoklaten, Gurah, Tarokan, Wates, Kepung, Ngancar, Mojo, Ngasem, Pagu, Gampengrejo, Semen dan juga Ngadiluwih. Nilai tersebut memiliki arti bahwa kecamatan-kecamatan tersebut tidak hanya mampu untuk memenuhi kebutuhan akan sirsak dalam kecamatannya akan tetapi kecamatan tersebut juga memiliki kelebihan produksi yang dapat dijual untuk kebutuhan kecamatan lainnya. Berdasarkan data yang telah diolah dapat diketahui bahwa Kecamatan Plosoklaten merupakan sentra terbesar atau daerah basis utama komoditas sirsak di kediri. Selama kurun waktu 6 tahun, produksi sirsak di kecamatan tersebut melimpah. Hal ini dikarenakan letak Kecamatan Plosoklaten yaitu tergolong dataran tinggi dan terdiri dari beberapa perbukitan. Sehingga kecamatan ini di Kabupaten Kediri sesuai untuk syarat tumbuh komoditas sirsak yang mampu hidup di dataran rendah hingga dataran tinggi sekitar 500 mdpl (Laksono, 2013).

Berdasarkan wawancara yang dilakukan dengan ketua kelompok Wonojoyo Trisulo, Bapak Suswandi, dapat diketahui bahwa sirsak yang dihasilkan memiliki perbedaan ukuran. Setelah petani menjual sirsak kepada pengepul maka sirsak berukuran besar langsung dibeli oleh restaurant dan juga langsung dijual di pasar. Grade menengah laku dijual di pasar dan dapat digunakan sebagai bahan baku produk olahan. Pengolahan sirsak ditujukan untuk meningkatkan nilai tambah.

\section{Kondisi UMKM Berbahan Baku Sirsak di Kediri}

UMKM Berbahan Baku Sirsak di Kediri dikelola oleh kelompok tani Wonojoyo Trisulo dan manajemennya dilakukan oleh Bapak Suswandi Susilo atau dipanggil dengan sebutan Pak Wandi. Dalam proses produksinya, Pak Wandi menggunakan beberapa alat pembantu, seperti 2 pengaduk bahan sari sirsak dan/atau dodol sirsak serta 1 buah capsiler sebagai alat bantu pengemasan sari sirsak. Bantuan alat didapatkan dari Disperta Kabupaten Kediri.

Menurut Pak Wandi, pengolahan dilakukan secara sederhana. Bahan baku dikupas kemudian direbus. Setelah itu bahan yang sudah matang akan ditiriskan untuk berikutnya diperas. Sari hasil perasan akan ditambahkan gula sebeleum akan direbus kembali. Setelah proses perebusan kedua selesai dilakukan, sari sirsak akan di press menggunakan cupsiler. Dalam sekali produksi, untuk menghasilkan 18 karton sari sirsak atau sama dengan 650 cup sari sirsak, diperlukan bahan baku seberat $12 \mathrm{~kg}$ sirsak belum dikupas atau setara dengan $8 \mathrm{~kg}$ sirsak matang. Bahan tambahan lain adalah gula sebanyak $4 \mathrm{~kg}$ 6ons dan air serta sedikit 
Tabel 2. Perhitungan Analisis SWOT Faktor Internal

\begin{tabular}{lllll}
\hline No. & Kekuatan & Bobot & Skala & B x S \\
\hline 1. & Bahan baku sirsak yang melimpah & 0,10 & 4 & 0,4 \\
2. & Gedung adalah milik sendiri & 0,04 & 2 & 0,08 \\
3. & Modal yang digunakan adalah modal sendiri & 0,04 & 2 & 0,08 \\
4. & Dukungan pemerintah yang cukup tinggi & 0,06 & 3 & 0,18 \\
5. & Produk hasil olahan sirsak tahan lama & 0,08 & 3 & 0,24 \\
6. & Nama produk sudah dikenal & 0,08 & 1 & 0,08 \\
\hline & & & & 1,06 \\
\hline No. & Kelemahan & Bobot & Skala & B x S \\
\hline 1. & Kurangnya mesin dan teknologi pengemasan & 0,12 & -4 & $-0,48$ \\
2. & Adanya atribut produk yang kurang menarik & 0,15 & -4 & $-0,60$ \\
3. & Harga Proses Produksi tinggi & 0,15 & -4 & $-0,60$ \\
4. & Kontinuinitas produksi terkendala permintaan & 0,03 & -3 & $-0,09$ \\
5. & Kurangnya tenaga pemasar & 0,09 & -4 & $-0,36$ \\
6. & Kurangnya pengetahuan pasar & 0,06 & -3 & $-0,18$ \\
\hline & & & & $-2,31$ \\
\hline
\end{tabular}

Sumber: Analisis Data Primer Tahun 2015

Natrium Benzoat. Jumlah tenaga kerja yang dibutuhkan adalah sebanyak 3 HOK dengan 9 jam kerja, mulai pukul $07.00-16.00$ untuk melakukan seluruh proses produksi. Satu HOK diberikan upah sebesar Rp 30.000,-

Dalam pemasaran sari sirsak merek dagang Axi, terdapat tiga pasar sebagai tempat distribusi pemasaran. Produk disalurkan secara langsung oleh produsen kepada Toko GTT (Gatot Tahu Taqwa), Rumah Batik Kediri "Suminar" yang berlokasi di kawasan Kampung Inggris, dan Toko oleh-oleh "Gokil". Dalam satu bulan, Pak Wandi mensuplai sebanyak 2 kali masingmasing sejumlah 10 cup minuman sari buah sirsak Axi untuk Toko GTT dan Rumah Batik Kediri "Suminar" serta 5 karton sari buah sirsak pada Toko Oleh-oleh "Gokil". Adapun isi dari setiap kartonnya adalah 36 cup. Permintaan terhadap minuman sari buah merek Axi akan meningkat saat menjelang dan pelaksanaan hari raya Idul Fitri. Bahkan permintaan seringkali sampai tidak dapat dipenuhi. Pak Wandi belum melakukan pemasaran kepada pedagang pengecer dikarenakan produk belum dapat bersaing dengan merek dagang lain seperti "Ale-Ale" dan "Siplaaah".

Kekuatan UMKM Produk Sirsak adalah adanya bahan baku yang melimpah. Sedangkan kelemahan lebih besar dari kekuatan terutama pada kurangnya mesin dan teknologi pengemasan, adanya atribut produk yang kurang menarik, dan kurangnya tenaga pemasar. Ancaman UMKM yaitu pesaing dari perusahaan besar terkait dengan merk dagang. Peluang yang dimiliki adalah karena produk ini cukup 
Tabel 3. Perhitungan Analisis SWOT Faktor Eksternal

\begin{tabular}{|c|c|c|c|c|}
\hline No. & Peluang & Bobot & Skala & $\mathrm{B} \times \mathrm{S}$ \\
\hline 1. & Ada pasar yang menampung dan belum dijajaki & 0,07 & 2 & 0,14 \\
\hline 2. & Produk unggulan berbasis sirsak cukup diminati & 0,11 & 4 & 0,45 \\
\hline 3. & Banyak permintaan pada moment tertentu. & 0,09 & 3 & 0,27 \\
\hline 4. & Kelembagaan masih dapat berkembang & 0,07 & 2 & 0,14 \\
\hline 5. & Pengembangan IT membuka peluang secara online & 0,05 & 1 & 0,05 \\
\hline \multirow[t]{2}{*}{6.} & Pangsa pasar produk mamiri yang selalu terbuka & 0,07 & 2 & 0,50 \\
\hline & & & & 1,54 \\
\hline No. & Ancaman & Bobot & Skala & $\mathrm{B} \times \mathrm{S}$ \\
\hline 1. & Pesaing dari perusahaan besar yang lebih enak rasanya & 0,11 & -4 & $-0,44$ \\
\hline 2. & MEA membanjiri pasar dengan produk serupa & 0,06 & -2 & $-0,11$ \\
\hline 3. & Petani lebih suka menjual dalam bentuk fresh. & 0,08 & -2 & $-0,17$ \\
\hline 4. & Persaingan merk dagang dengan perusahaan lain & 0,14 & -4 & $-0,55$ \\
\hline 5. & Harga produk lain yang lebih murah & 0,11 & -3 & $-0,33$ \\
\hline \multirow[t]{2}{*}{6.} & Tenaga kerja belum tetap menyebabkan produksi tidak kontinu & 0,06 & -1 & $-0,06$ \\
\hline & & & & $-1,65$ \\
\hline
\end{tabular}

Sumber: Analisis Data Primer Tahun 2015

diketahui dan diminati oleh masyarakat.

Analisa SWOT dilakukan dengan mengidentifikasikan faktor internal dan eksternal UMKM pengolahan berbahan baku sirsak terlebih dahulu. Kemudian bobot, skor dan rating ditentukan berdasarkan faktor yang terpenting. Hasil Perhitungan dari kekuatan UMKM sirsak di Kecamatan Plosoklaten yaitu meliputi :

a) bahan baku sirsak yang melimpah dengan nilai bobot skala 0,4 karena produksi sirsak cukup tinggi sebagaimana yang ditunjukkan oleh tabel 4. Selama kurun waktu tujuh tahun, dapat dilihat bahwa produksi sirsak di Kecamatan Plosoklaten Kabupaten Kediri mengalami fluktuasi, namun demikian rata-rata pertahunnya adalah sekitar 30.866 kuintal.
Tabel 4. Produksi sirsak di Kecamatan Plosoklaten Kabupaten Kediri

\begin{tabular}{ccc}
\hline No. & Tahun & $\begin{array}{c}\text { Produksi } \\
(\mathrm{kw})\end{array}$ \\
\hline 1 & 2009 & 35.019 \\
2 & 2010 & 33.185 \\
3 & 2011 & 35.900 \\
4 & 2012 & 39.215 \\
5 & 2013 & 26.546 \\
6 & 2014 & 39.215 \\
7 & 2015 & 38.978 \\
\hline \multicolumn{2}{c}{ Rata-rata } & $30.866,29$ \\
\hline
\end{tabular}

Sumber: BPS, 2015

b) Bangunan tempat didirikannyaUMKM produksi sirsak ini adalah milik sendiri dengan nilai bobot skala 0,08 yang tentunya menjadi kekuatan UMKM ini karena tidak harus menyewa gedung untuk produksi. 
c) Modal sendiri merupakan faktor yang menjadi kekuatan yang sangat penting dengan bobot skala 0,08 karena modal tidak didapatkan dari sumber lain.

d) Dukungan pemerintah yang cukup tinggi memiliki nilai bobot skala 0,18 menjadi kekuatan UMKM ini untuk terus berkembang.Sampai saat ini pemerintah daerah memberikan dukungan yang cukup tinggi terhadap perkembangan produksi Sirsak di Kecamatan Plosoklaten. menurut Disperta, pasar sirsak memiliki permintaan besar akan sirsak yang dipasarkan dalam kondisi masih segar. Sirsak ini akan digunakan untuk memenuhi kebutuhan hotel dan restoran. Dukungan pemasaran produk dapat dilihat dari penyaluran secara rutin pada Kantor Kecamatan, Dsperta Kabupaten Kediri, Puskesmas Pranggang, jika terdapat hajatan atau acara khusus pada lembaga-lembaga tersebut. Diperta juga telah memberikan bantuan dalam bentuk kemasan produk pada Gambar 3.

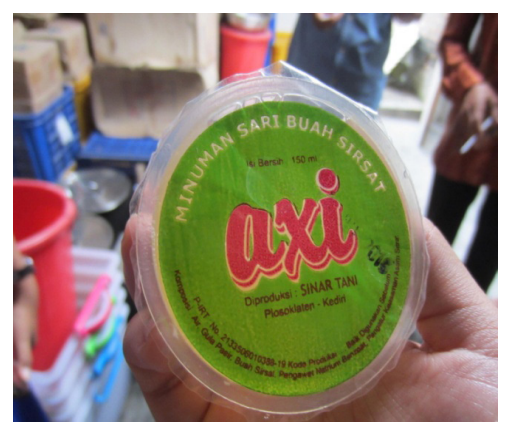

Gambar 3. Kemasan Produk AXI e) Produk hasil olahan sirsak tahan lama memiliki nilai bobot 0,24 . Hal ini bukan menjadi pertimbangan kekuatan produk olahan, karena produk olahan sirsak ini diolah dengan pengemasan yang cukup tahan lama kurang lebih selama 3 bulan.

f) Nama produk sudah dikenal memiliki nilai bobot 0,08 karena produk olahan sirsak ini sudah dipasarkan dan sudah dikenal oleh konsumen dalam kota Kediri. Sehingga dapat dikatakan permintaan terhadap produk selalu konstan dan cenderung meningkat.

Hasil perhitungan SWOT faktor internal ditinjau dari kelemahan UMKM sirsak di Kecamatan Plosoklaten meliputi :

a) Kurangnya mesin dan teknologi pengemasan memiliki nilai bobot $-0,48$ karena terbatasnya mesin teknologi pengemasan yang menjadikan proses pengemasan menjadi lebih lambat. Pertama, Mesin Pengemas/Cup sealer yang digunakan masih menggunakan mesin manual sehingga masih diperlukan perlakuan untuk merapikan tutup kemasan sebelum dikemas dalam karton. Hal ini dapat mengakibatkan waktu produksi yang lebih lama. Kedua, Tidak adanya tata letak fasilitas yang baik. Mesin tidak ditata dengan baik sehingga pergerakan operatornya dapat terganggu.

b) Adanya atribut produk yang kurang menarik memiliki nilai bobot $-0,60$ 
karena desain kemasan yang dirasa masih sederhana dan belum bisa menarik konsumen.Misalnya adalah Pertama, pencantuman label tanggal kadaluarsa masih menggunakan teknik manual yaitu dengan stempel. Jika produk disimpan dalam lemari pendingin maka lama kelamaan label tanggal kadaluarsanya dapat hilang. Hal ini dapat membahayakan konsumen. Kedua, Cup kemasan minuman sari buah yang transparan memberikan kesan kurang menarik pada produk yang diakibatkan adanya endapan sari sirsak. Cup merupakan bantuan Disperta kepada produsen, akan tetapi endapan belum dapat dinetralkan sehingga perlu disiasati dengan cup tidak transparan. Sedangkan dari pihak Disperta hanya bersedia memberikan bantuan cup sama seperti yang sedang digunakan untuk pengemasan saat ini.

c) Harga Proses Produksi tinggi memiliki nilai bobot $-0,60$ yang tentunya menjadikan proses produksi kurang efisien dan harga jual yang lebih mahal. Harga Jual minuman sari buah yang terlalu mahal yaitu sebesar Rp 750,per 150 dapat menyebabkan konsumen lebih memilih minuman dengan merek dagang lain dengan harga lebih rendah tetapi memiliki volume lebih banyak.

d) Kontinuinitas produksi terkendala permintaan memiliki nilai bobot $-0,09$ karena permintaan yang tidak menentu menjadikan UMKM olahan sirsak ini belum bisa memastikan permintaan yang pasti setiap waktunya.

e) Kurangnya tenaga pemasar memiliki nilai bobot $-0,36$ karena terbatasnya SDM pemasaran yang ada sehingga proses pemasaran produk kurang maksimal. Keterbatasan tenaga pemasar ini, dikarenakan pada minuman sari buah hanya mengandalkan satu orang tenaga saja untuk produksi dan satu orang ini juga melakukan kegiatan lain seperti pemsaran dan administasi.

f) Kurangnya pengetahuan pasar memiliki nilai bobot $-0,18$ karena produsen dirasa kurang aktif dalam meningkatkan jaringan pasar.Produsen belum dapat memperkirakan pangsa pasar minuman sari buah serta belum memiliki pelanggan tetap.

Hasil perhitungan SWOT faktor eksternal ditinjau dari peluang UMKM sirsak di Kecamatan Plosoklatenmeliputi :

a) Ada pasar yang menampung dan belum dijajaki memiliki nilai bobot 0,14 karena menjadi peluang yang bagus agar produk bisa memperluas jangkauan pasar. Industri makanan dan minuman menjadi salah satu sektor yang cukup berkembang di Kabupaten Kediri, sehingga masih banyak pasar yang dapat ditembus misalnya toko oleh-oleh khas Kediri seperi Poo, Lym, GTT dan Koperasi Oleh-oleh Dinas 
Koperasi. Selain itu, jika perbaikan yang dilakukan terhadap kemasan dilakukan dengan baik, maka tidak menutup kemungkinan pangsa pasar modern seperti Kediri Mall, Carefour dan Golden Market dapat menjadi peluang untuk pemasaran berikutnya.

b) Produk unggulan berbasis sirsak cukup diminati memiliki nilai bobot 0,45 karena menjadi peluang yang sangat bagus ketika produk olahan sirsak didaerah penelitian belum ada yang mendominasi.

c) Banyak permintaan pada moment tertentu memiliki nilai bobot 0,27 karena permintaan pada momentmoment tertentu menjadi peluang yang sangat positif untuk meningkatan penjualan misalnya adalah moment hari besar keagamaan seperti Idul Fitri dan Hari Natal.

d) Kelembagaan masih dapat berkembang memiliki nilai bobot 0,14 karena kelembagaan UMKM sirsak ini dirasa masih bisa dikembangkan dengan memperbaiki aspek-aspek yang belum maksimal. Kelembagaan UMKM Wonojoyo Trisulo ini merupakan milik dari Kelompok tani dengan nama yang sama yaitu Wonojoyo Trisulo. Sampai saat ini SDM yang berperan masih terbatas, namun tidak menutup kemungkinan jika manajemen yang dilakukan lebih baik, maka segi kelembagaan akan dapat diperbaiki. e) Pengembangan IT membuka peluang secara online memiliki nilai bobot 0,05 karena dengan pengambangan teknologi ini tentunya bisa memperluas jaringan pasar dengan sangat cepat.

f) Pangsa pasar produk yang selalu terbuka memiliki nilai bobot 0,50 karena produk ini dirasa masih sangat bisa untuk memperluas pangsa pasarnya.

Hasil perhitungan SWOT faktor eksternal ditinjau dari ancaman UMKM sirsak di Kecamatan Plosoklatenmeliputi :

a) Pesaing dari perusahaan besar yang memiliki produk lebih stabil dan kompetitif memiliki nilai bobot $-0,44$ karena produk dari kompetitor dirasa lebih menarik dan proses produksinya dengan teknologi massal, sehingga jumlah produk yang dijual dalam toko selalu konstan.

b) MEA membanjiri pasar dengan produk serupa memiliki nilai bobot $-0,11$ karena dengan dtetapkannya kebijakan MEA, menjadikan persaingan pasar lebih berat dengan masuknya produsen asing yang masuk.

c) Petani lebih suka menjual dalam bentuk fresh memiliki nilai bobot -0,17 karena kurang adanya minat dari petani sirsak untuk mengolah sirsak menjadi produk yang mempunyai nilai tambah.

d) Persaingan merk dagang dengan perusahaan lain memiliki nilai bobot 
-0,55 karena persaingan merk dagang menjadi lebih sengit dengan semakin banyaknya produsen serupa.

e) Harga produk lain yang lebih murah memiliki nilai bobot -0,33 karena produk kompetitor yang dijual lebih murah menjadi ancaman yang sangat sulit untuk produk ini memasuki pasar.

f) Tenaga kerja belum tetap menyebabkan produksi tidak kontinu memiliki nilai bobot $-0,06$.

\section{Strategi Penguatan Kelembagaan UMKM Pengolahan minuman berbahan baku Sirsak}

Strategi penguatan kelembagaan dapat dilihat dari memformulasikan faktor internal dan eksternal yang sudah teridentifikasi dalam matriks kedalam kuadran-kuadran SWOT sebagaimana dapat dilihat pada Gambar 4.

Koordinat titik $(-1,25 ;-0,12)$ menunjukkan posisi UMKM produk sirsak berada di kuadran IVweakness-threat (negatif, negatif). Posisi ini menandakan kondisi produsen produk sirsak yang lemahdan dilematis karena berada padapertemuan kelemahan produsen produk sirsak dengan ancaman dari luar, dan karenanyakeputusan yang salah dapat menghancurkan perusahaannya. Strategiyang harus diambil adalah strategi damage control (mengendalikan kerugian untuk menghindari ancaman). Hal tersebut dapat dilakukan dengan strategi di kuadrat IV (W-T), yaitu strategi defensif dengan mengendalikankinerja internal agar tidak semakin terperosok. Strategi ini dipertahankan sambilterus berupaya membenahi diri.

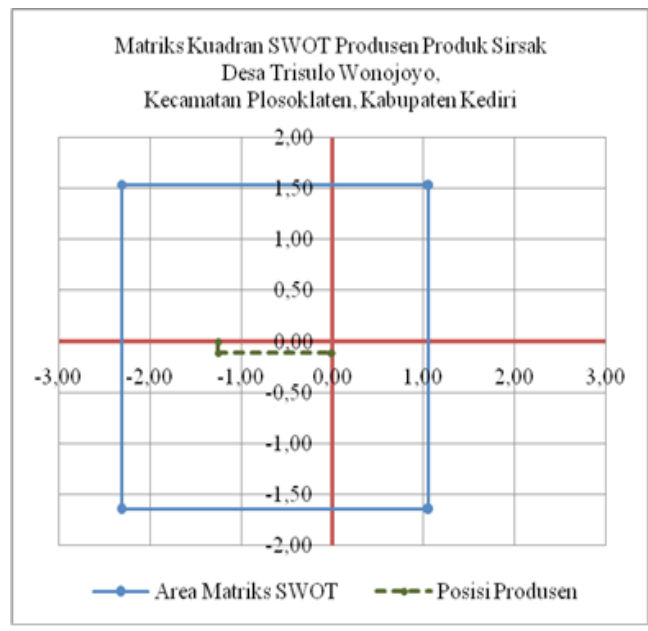

Gambar 4. Matriks Kuadran SWOT Produsen Sirsak

Berikut adalah matriks kuadran SWOT yang menunjukkan output berupa solusi yang telah dirumuskan untuk mempertahankan UMKM dengan upaya meminimalkan kelemahan internal serta mengatasi ancaman eksternal:

\section{Strategi Peningkatan Kualitas}

SDM. Kelemahan terkait dengan pengetahuan pasar dapat diatasi dengan pemberian pelatihan kepada pemilik UMKM misalnya tentang sales marketing dan bagaimana serta apa saja informasi yang perlu digali dalam pasar. Informasi pasar tersebut dapat meliputi pembentukan harga, harga produk itu sendiri, jumlah produsen 
dan pembeli dalam pasar, kebijakan dan peraturan yang berlaku dalam pasar, lembaga dan organisasi yang terkait dalam pemasaran. Diharapkan dengan kemampuan yang dimiliki, maka pemilik UMKM dapat memiliki intuisi dan wawasan yang tinggi dalam memanfaatkan peluang pasar.

\section{Strategi Peningkatan Teknologi.}

Peningkatan kualitas dan produktivitas minuman sari buah Sirsak memerlukan adanya peningkatan pemahaman dan pengetahuan tentang penggunaan teknologi pengolahan. Program hibah bantuan peralatan oleh pemerintah dan pihak swasta dapat dilakukan misalnya dengan menambahkan alat filter dan mesin cupsealersemi otomatis. Hal ini akan menghemat jam kerja tenaga pengemas sehingga dapat menekan biaya tenaga kerja. Selain itu kemasan tidak transparan merupakan alternatif terbaik untuk sementara sebelum pengadaan mesin penetral endapan dapat dipenuhi. Mesin labeling expired date sangat dibutuhkan oleh UMKM utamanya untuk menunjukkan hingga kapankah produk dapat dikonsumsi. Kondisi saat ini, produsen masih menggunakan stempel tanggal untuk mencetak label expired date. Permasalahannya label yang dicetak tidak mampu bertahan lama dan mudah pudar terutama jika minuman disimpan di dalam lemari pendingin. Label yang pudar dapat membahayakan konsumen dikarenakan tanggal expired date yang tercetak menjadi tak terlihat.

\section{Penguatan Strategi Pemasaran.}

Kurangnya pengetahuan pasar oleh produsen dapat diatasi dengan pemberian pelatihan kepada dua atau tiga orang pemasar terkait dengan strategi pemasaran, misalnya penjualan dengan memperhatikan bauran pemasaran atau marketing mix. Strategi marketing mix menunjukkan bahwa pemasaran produk yang baik adalah dengan memperhatikan $4 \mathrm{P}$ yaitu product, price, promotion and place (distribution). Product berkaitan dengan pengetahuan pemasar terkait dengan atribut cita rasa sesuai dengan yang disukai oleh konsumen. Place atau Distribution adalah bagaimana cara produk didistribusikan dengan baik. Hal ini melibatkan cara-cara yang perlu dipahami, agar produk sampai dengan baik ke tangan konsumen. Selain dengan menitipkan kepada toko oleh-oleh, UMKM produk minuman sirsak Wonojoyo Trisulo juga bisa mulai membuka outlet atau toko di tempat strategis agar konsumen yang berminat dapat mengetahui bagaimana cara menemukan produknya. Promotion dapat dilakukan dengan memberikan potongan penjualan manakala membeli 
dalam jumlah yang banyak sedangkan

price adalah pengetahuan terkait dengan penetapan harga jual.

Dengan kuatnya pengetahuan pasar tersebut, dimungkinkan pemilik UMKM Wonojoyo Trisulo akan sekaligus mampu dalam melakukan peramalan permintaan produk olahan sirsak di pasar, sehingga tidak sampai menghambat kontinuitas produksi produk olahan sirsak. Pengetahuan pasar terkait dengan pembentukan harga, harga produk itu sendiri, jumlah produsen dan pembeli dalam pasar, kebijakan dan peraturan yang berlaku dalam pasar, lembaga dan organisasi yang terkait dalam pemasaran serta kolusi dan kerjasama yang dimungkinkan mendominasi pasar. Selain hal tersebut maka hal penting lainnya yang perlu diperhatikan adalah:

a) Perlu adanya terobosan pemasaran misalnya dengan memasukkan ke toko oleh-oleh yang berada di Kota atau Kabupaten Kediri

b) Perbaikan manajamen pemasaran dengan cara menindaklanjuti toko toko besar yang telah melakukan pemesanan sebelumnya.

c) Pemasaran dapat dilakukan dengan menggunakan personal selling yaitu memanfaatkan tenaga kerja yang digaji untuk melakukan tugas pemasaran, yaitu misalnya mengantarkan barang, mencari pasar baru dan mengecek persediaan barang di toko serta melakukan retur apabila barang tersebut sudah kedaluarsa.

\section{Penguatan Strategi Manajemen} Usaha Berbasis Kewirausahaan. Melihat kondisi sebenarnya dari usaha UKM Produk sirsat perlu dilaksanakan dengan lebih profesional, dimana dalam hal ini usaha harus lebih berorientasi pada bisnis yang menghasilkan keuntungan.

\section{KESIMPULAN DAN SARAN}

\section{Kesimpulan}

Kabupaten Kediri terdiri dari 13 wilayah sentra komoditas Sirsak dengan wilayah basis tertinggi adalah Kecamatan Plosoklatenyang menjadikannya lokasi representatif bagi UMKM Pengolahan Sirsak. UMKM tersebut memiliki kelemahan dan ancaman yang cukup besar jika dibandingkan dengan kelebihan dan tantangannya. Strategi yang digunakan untuk penguatan kelembagaan UMKM adalah adalah Damage Control misalnya dengan penguatan strategi peningkatan SDM, strategi peningkatan teknologi, dan penguatan strategi pemasaran agar dilaksanakan sebagai murni bisnis secara profesional.

\section{Saran}

Berdasarkan hasil kesimpulan penelitian yang didapat maka saran yang penulis berikan untuk UMKM sirsak adalah mempertahankan perusahaan dengan upaya 
meminimalkan kelemahan internal serta mengatasi ancaman yang ada. Strategi yang dapat digunakan untuk meminimalkan kelemahan internal dan mengatasi ancaman adalah dengan strategi peningkatan SDM, strategi peningkatan teknologi dan penguatan strategi pemasaran. Perlu adanya dukungan pengadaan peralatan alat untuk menjamin ketersediaan produk. Namun hal tersebut tidak akan berjalan dengan baik tanpa adanya manajemen usaha yang baik, didukung dengan dukungan pemasaran. Penguatan kapabilitas dan penambahan sumber daya utamanya adalah pemasaran sangat diperlukan.

\section{DAFTAR PUSTAKA}

Badan Pusat Statistik Kabupaten Kediri, 2015.Kabupaten Kediri dalam Angka Tahun 2015. Kediri : Badan Pusat Statistik.

Hendayana, 2003. Aplikasi Metode Location Quotient (LQ) dalam Penentuan Komoditas Unggulan Nasional: Jurnal Informatika Pertanian 12 (1) : 1-21
Hermawan, G.P., dan H. Laksono,(2013), Ekstraksi Daun Sirsak (Anona muricata) menggunakan Pelarut Etanol. Jurnal Teknologi Kimia dan Industri. 2 (2) : 111-115

Prihtanto, F. N.P, Irham dan A. Suryantini 2015.Analisis Industri Rumah Tangga Gula Semut untuk Ekspor di Kabupaten Kulon Progo dan Purworejo. Agro Ekonomi 26(1):22-23

Rahayu, P dan Navastara, A.M. 2012. Penentuan Wilayah Potensial Komoditas Jagung di Kabupaten Kediri. Jurnal Teknik Pomits. 3(1):24-27

Rangkuti.2006. Analisis SWOT: Teknik Membedah Kasus Bisnis Reorientasi Konsep Perencanaan Strategis untuk menghadani Abad 21. Jakarta: PT. Gramedia Pustaka Utama.

Wibowo. R dan Januar. J. 1998. Teori Perencanaan Pembangunan Wilayah. Jember : Jurusan Sosial Ekonomi Pertanian Fakultas Pertanian Universitas Jember. 